Beyond Philology No. 15/1, 2018

ISSN 1732-1220, eISSN 2451-1498

\title{
Levels of categorization in animal idiomatic expressions
}

\author{
OLGA SOKOŁOWSKA
}

Received 21.02.2018, received in revised form 24.06.2018, accepted 29.06.2018.

\begin{abstract}
The departure point for the considerations presented below is Lakoff's (1982, 1987) remark about the "greater cultural significance" of categories of the basic level of cognition, which can be recognized by a variety of criteria, among others - the criterion of their lexical labels functioning as basic terms in language. To verify that idea and to apply it to the important aspect of the cognized world constituted by the fauna, it is assumed that cultural significance should be confirmed by the occurrence of images of animals representing a certain level of classification in pictorial art and, also, by the occurrence of basic animal terms referring to basic animal categories in some kinds of literary works of art and, above all, in idiomatic expressions typically representing metaphorical meaning. The survey of a sample of English idioms provided by a selected dictionary largely confirms Lakoff's statement as, indeed, basic category terms are the most common ones functioning in established idiomatic English animal expressions, although more specific subcategory names, especially as regards the class of birds, also appear in them in a significant number,. What can also be concluded from the analyzed material is the fact that the basic level of categorization, termed by Lakoff the folk generic level only very loosely corresponds to the scientific generic level, which is basic in the Linnaean taxonomy. The scientific levels corresponding to the folk basic one can range from those of class
\end{abstract}


(birds), through order (bats), family (hares), genus (rats), to species (dogs, cats, horses). The reason seems to be the fact that folk animal categories are determined by properties which are relevant in casual, practical-use-oriented cognition, which, nevertheless, need not be significant for establishing scientific taxonomies.

\title{
Keywords
}

categorization, basic level, idiom, connotation, folk and scientific taxonomy

\section{Poziomy kategoryzacji w zwrotach idiomatycznych odnoszących się do zwierząt}

\begin{abstract}
Abstrakt
Punktem wyjścia dla przedstawionych poniżej rozważań jest uwaga Lakoffa $(1982,1987)$ o szczególnie istotnym znaczeniu kulturowym kategorii podstawowych poznania, które moga być rozpoznane przy pomocy szeregu kryteriów. Jednym $z$ nich jest osiagnięcie statusu podstawowych terminów języka przez etykiety leksykalne takich kategorii. W celu zweryfikowania tego stwierdzenia i odniesienia go do ważnego aspektu przedmiotu ludzkiego poznania, jakim jest świat fauny, przyjęta została teza, że znaczenie dla kultury określonego poziomu kategoryzacji zwierzat powinno być potwierdzone przez jego odbicie w sztuce figuratywnej, a także przez występowanie podstawowych terminów odnoszących się do podstawowych kategorii zwierzęcych w literaturze oraz, przede wszystkim, w ustabilizowanych idiomach typowo reprezentujacych znaczenie metaforyczne. Analiza próbki zwrotów „zwierzęcych” zaczerpniętych $z$ wybranego słownika idiomów angielskich potwierdza tezę Lakoffa wskazując iż, rzeczywiście, nazwy zwierzat poziomu podstawowego sa najczęściej występującymi w idiomach terminami odnoszącymi się do fauny, chociaż swoja znaczaca liczebnie obecność zaznaczaja też nazwy kategorii bardziej szczegółowego poziomu niższego niż podstawowy, szczególnie, jeśli chodzi o klasę ptaków. Inny ważny wniosek wypływający $z$ przeprowadzonej analizy to stwierdzenie faktu, że podstawowy poziom kategoryzacji odzwierciedlany przez język potoczny, nazwany przez Lakoffa poziomem „ludowym”, jest tylko bardzo luźno przysta-
\end{abstract}


jaccy do poziomu rodzaju (genus), który jest bazowy w naukowej taksonomii organizmów żywych wywodzącej się $\mathrm{z}$ tradycji linneuszowskiej. Kategorie opisu naukowego odpowiadajace podstawowemu poziomowi „ludowemu” obejmuja naukowe jednostki taksonomiczne od klasy (ptaki), poprzez rzad (nietoperze), rodzine (zajace) i rodzaj (szczury), po gatunek (psy, koty, konie). Przyczyna tych rozbieżności wydaje się być to, że „ludowe” kategorie zwierzęce ustanowione sa na podstawie identyfikacji cech istotnych $\mathrm{w}$ poznaniu codziennym, potocznym, nastawionym na cele praktyczne, które to cechy nie musza mieć znaczenia w budowaniu taksonomii naukowej.

\section{Slowa kluczowe}

kategoryzacja, poziom podstawowy, idiom, konotacja, taksonomia „ludowa” i naukowa

\section{Introduction}

As a most relevant and inseparable part of the reality in which every human community functions, animals inspire conceptions that are inherent in the model of the world created by the human mind. Since it is predominantly language that offers access to that mental model, it seems worthwhile to consider the image of fauna representatives recorded in its important aspect, such as idiomatic expressions, which, in turn, are closely related to culture, within which any language operates.

\section{Basic cognitive categories and basic language terms}

The idea of human-determined basic levels of cognition and categorization is, next to that of category prototypes, a fundamental assumption in cognitive epistemology and, consequently, approach to language. Indeed, the discovery that the human mind operates most efficiently when it deals with categories of a certain degree of schematicity/specificity (neither too schematic nor too specific), which was the result of the research into human cognition accomplished by the anthropolo- 
gist Brent Berlin and the psychologist Eleanor Rosch is, next to the discovery of the significance of prototypes in categorization, a cornerstone in the development of cognitive linguistics (cf. Lakoff 1987: 46-54). It is especially relevant to lexical semantics, as it explains not only the special status of lexemes referring to them entertained in everyday conversations as well as language acquisition and learning, but also the morphological shape of lexemes and their usually unproblematic translatability. Thus, the so-called basic terms are not only used more frequently and learnt sooner, but they also assume simpler, as it were, easier to pronounce morphological forms and, additionally, there is a high chance of their cross-language equivalence. Their formal functionality is strictly connected with informative efficiency which is, as observed by Taylor (2002: 132), "maximal". This results from the fact that they name categories that exhibit optimal combinations of characteristics recognized as most relevant from the human point of view. As indicated by Lakoff (1987: 269), "[human] experience is preconceptually structured at that level". It is also at this level that categories are represented by the clearest Idealized Cognitive Models constituting readily manageable mental gestalts. Such facts lead to the conclusion that the priority given to certain categories in human cognition is determined not only by those categories themselves (they typically constitute good perceptual gestalts) but also by the capacities of the human mind. Moreover, it is important to note, as Lakoff does (1987: 270) that "we have basic level concepts not only for objects but also for actions and properties as well".

\section{The cultural relevance of basic level categories}

It is of course, impossible to empirically explore conceptions as such, therefore the basicness of specific categories must be recognized with respect to certain explicit, verifiable criteria. Thus, Lakoff (1987: 33), proposing that the categories recognized by the human mind at what he calls, after Berlin, folk- 
generic level, are psychologically basic, specifies certain criteria that testify for that status as follows:

1. People name things more readily at that level.

2. Languages have simpler names for things at that level.

3. Categories at that level have greater cultural significance.

4. Things are remembered more readily at that level.

5. At that level, things are perceived holistically, as a single gestalt $[\ldots]$.

Apart from the strict connection between basic conceptions and basic language terms referring to them mentioned in the above-mentioned list, the criterion which is of particular relevance to the purposes of the present paper is specified in the third point, which concerns cultural significance. However, unlike the remaining criteria, which have been experimentally verified by Brown and Berlin (cf. Lakoff 1987: 31-34), this one is somewhat vague and calls for some elaboration and explanation as to what "cultural significance" actually means.

Indeed, the notion of culture seems to be one of the imponderables that cannot be briefly and conclusively defined. One of the reasons is probably the fact that it encompasses practically every aspect of human activity. Nevertheless, for the purposes of the present paper it is useful to consider part of the definition provided by Webster's New World Dictionary of the American Language, which states that culture comprises "ideas, customs, skills, arts, etc. of a given people in a given time, [and] civilization".

Some aspects of culture so defined, in which the relevance of basic level animal categories seem to be particularly recognizable, are the following:

- pictorial representations, in e.g., art, heraldry, road signs and other popular pictograms and ideograms;

- language: apart from the common use of basic animal terms in everyday conversations, references to them in literature as well as in fixed expressions, such as idioms and proverbs. 
As regards animal literary characters, perhaps the most typical genre in which they can be found is fables, whose long tradition was established in Ancient Greece by Aesop and has thereafter been continued in European literature (La Fontaine, Krasicki). A brief look at several selected titles of such texts confirms the cultural relevance of basic animal terms employed in them, which indeed evoke rich images laden with characteristics vital for the fables' moralizing function. Some examples are: The Bear and the Bees; The Fox and the Lion; The Peacock's Complaint; The Tiger and the Crane; The Tortoise and the Hare; The Wolf and the Crane (Aesop), and The Ass and the Dog; The Cat and the Sparrows; The Crow and the Fox; The Dove and the Ant; The Fox and the Stork; The Fox and the Turkeys; The Lion, the Wolf and the Fox; The Monkey and the Cat; The Monkey and the Leopard; The Two Pigeons; The Rat and the Elephant; The Vultures and the Pigeons; The Wolf and the Dog (La Fontaine).

It should be emphasized that the animal terms involved refer to the basic (folk generic) level of categorization and, as such, evoke the optimal amount of casual, popular knowledge contained within the respective animals' ICMs. A small but notable exception to this general tendency is constituted by ornithological terms, which describe their referents at a level more specific than basic, referred to by the lexeme bird. This issue will be tackled in the subsequent parts of the present paper.

\subsection{Animal cognitive models}

Animal categories are some of the most popular ones addressed when illustrating the ideas of prototypes and basic cognitive levels with examples is at issue. The reason seems to be the fact that they constitute specifically conspicuous and important elements of the surrounding reality. In casual human cognition it is unproblematic to recognize the similarities between the members of the same basic level animal category 
and assign the status of prototypes to those of its members that display the maximum number of attributes relevant to that category's function in the human mental model of the world. By the same token, it is equally unproblematic for the human eye to discern dissimilarities between distinct basic level animal categories. However, what is relevant to categorization and naming specific phenomena by language is the establishing of conceptions inspired by experience with real representatives of the fauna, i.e., their idealized cognitive models.

Thus, animal cognitive models, labelled by language terms, comprise extensive, often casual or naïve, knowledge (in terms of a number of lower-order conceptions, i.e., cognitive domains) accumulated on the basis of experience. Some of these domains constitute what is traditionally referred to as the designation of a given word, while some others are identifiable as its connotations. In cognitive linguistics, connotations are not considered to be an additional or secondary aspect of meaning, but rather, to constitute an integral part of the semantic structure represented by a given lexeme (cf. Taylor 2002: 201-202). It seems that the "cultural significance" of certain basic-level categories, especially animal ones, is determined by those lower-order conceptions involved in a specific cognitive model that would traditionally be identified as connotations of a respective word. Among the lexemes referring to all kinds of natural phenomena established in each language it is those concerning certain animals closely connected with humans and their lifestyle that activate specifically rich connotations, which, in turn, determines the common use of the respective animal terms in popular idioms and sayings.

\subsection{Animal cognitive models as source domains in metaphorical mappings}

Anthropomorphizing animals has found its expression in folk tradition (fairy tales) as well as literature (fables). Many stereotypes of animals, especially of those which are particularly 
close to human experience, include conceptions of human attributes. This probably results from the interpretation of certain natural forms of behaviour of specific kinds of creatures. As a result, there emerge popular convictions of the "courage" of lions, the "nobility" of eagles, the "slyness" of foxes, the "wisdom" of owls, the "treacherousness" of snakes, etc. It seems to be the axiological evaluation of those attributes in humans that predestines particular animal models endowed with them as source domains in metaphorical mappings on which the meaning of idiomatic expressions is based. The following fable by Ignacy Krasicki Lew $i$ zwierzęta 'The Lion and the Animals' constitutes a good illustration of connotative associations ascribed to particular creatures which participate in their respective idealized cognitive models (an attempt at translation from Polish by the present author ${ }^{1}$ ):

When all the animals came the lion to see

They held debate: what trait in creatures best should be?

The elephant cherished prudence, the bison - gravity,

The camels - self-restraint, the leopards - audacity,

The bear spoke up for power, the horse - for shapely frame,

The wolf - for skill to track and catch his game,

The roe praised subtle beauty, the hart fair horns extolled,

The hare was all for fleetness, the lynx - for raiment bold,

The dog commended loyalty, the fox - a clever brain,

The sheep exalted meekness, the ass - hard work and strain.

At last, announced the lion, "Truly, of every beast

That one is the worthiest that brags the least."

\section{Idioms and proverbs}

As has been indicated, another important aspect of culture in which basic level categories acquire a special significance is the inventory of idioms and proverbs functioning in the language on which a given culture is based. Although the two cat-

${ }^{1}$ I wish to express my deepest gratitude to Professor Jean Ward of the University of Gdansk for her help in rendering Krasicki's verses in English. 
egories seem to be very much alike, they in fact serve quite different functions in discourse. Idioms, which are used as a form of expression, implicitly attend to the representative (expositive) illocutionary force of utterances of which they are part, i.e., they participate in descriptions of situations as conceived by speakers, thus entering into the words-to-world relationship (cf. Searle 1977). Proverbs, which by capturing popular truths offer advice about the way to live a life, constitute implicit directives meant to establish the world-to-words arrangement. Nevertheless, there are indubitable similarities between both categories of phraseological units, whose meaning is "greater" than their propositional contents, i.e., it is noncompositional. The relevant, intended to be communicated, meaning of proverbs is in fact idiomatic since it is different from the literal. Moreover, the sense of both types of expressions is usually figurative, metaphorical. When it comes to the actual metaphorical mappings involved in idioms as well as proverbs which, making use of animal terms, refer to various representatives of the fauna as source domains, the target notions are invariably constituted by humans: human properties, human ways of behaviour, human concerns, etc. The following study of idiomatic expressions pertaining to the category of phenomena in question, i.e., animals, is based on the material provided by the selected source, The Penguin Dictionary of English Idioms by Daphne M. Gulland and David G. Hinds-Howell (1986).

\section{The study material}

When considering the animal-appealing idiomatic and proverbial phrases with regard to the source domains in the metaphorical mappings which they involve, their number is indeed considerable. A quick glance at the thematic sections into which the language material provided by the above-mentioned source is divided, reveals that the sections comprising idioms based on faunal terms (the category labelled "animals" has 
been distinguished from those referring to "birds", "fish" and "insects") is second in size ( 390) only to the section involving terms for human body parts ( 730), and larger than those concerning foods $(\sim 170)$, clothes $(\sim 160)$ and furniture or household articles ( 120). Indubitably, one's own body constitutes a source domain that is the closest of all to human experience, therefore it participates in metaphorical mappings on which many idioms are based. Nevertheless, the fact that the fauna constitutes the second most prolific reservoir of inspirations for such expressions strongly supports the assumption of its significance in the mental model of the world constructed by language speakers. Of course, the considered idiom dictionary provides only examples from English, but there is no reason to assume that other languages are considerably different in this respect.

The aforementioned traditional dictionary, a solid, printed source from which to excerpt a limited sample of animal expressions has been selected for heuristic reasons. Firstly, it provides a manageable number of examples compiled by native speakers of British English, secondly, depending upon it alleviates the necessity of deciding what is and what is not an idiom. The latter issue has become especially problematic in view of Turner and Fauconnier's theory of conceptual blends (1995), which proposes that practically any complex expression in a language represents a meaning in the recognition of which circumstantial knowledge (mental context) plays a vital role.

The sample comprises a total number of 365 expressions, each of which involves a word referring to a real animal. The few expressions which involve fictitious creatures like the Cheshire Cat, the March Hare or dragons, or involve terms for phenomena related to animals, such as, wing, nest, caviar, rather than entire animal conceptions have been omitted. This number is most probably only a fraction of idiomatic animal phrases coined by speakers of English, and certainly new ones have appeared since the book was first published (1986). Nevertheless, the sample size seems sufficient for a study designed 
to confirm Lakoff's statement that basic level categories labelled by basic language terms are indeed culturally more significant that non-basic ones.

All in all, despite its limitations, the selected source provides a dependable sample of expressions of confirmed idiomatic character. This sample has constituted the basis for the analysis described below and certain conclusion that have been drawn therefrom.

\section{Animal terms and models in selected English idiomatic expressions}

As already mentioned, the idiomatic expressions which involve animal terms in the selected source are only second in number to those concerning human body parts. They have been further divided into four groups according to criteria based on common, folk taxonomy of the fauna, as the listed expressions are grouped into those mentioning ANIMALS, BIRDS, FISH and INSECTS (curiously, the few provided idioms involving terms for mollusks, such as snail, leech or limpet are included in the INSECT category). Their total number approaches 400 but a few refer not to specific creatures but to notions such as wings, nests, molehills, caviar, cobwebs, which, nevertheless, participate in higher-order basic animal concepts. A study of actual terms involved in the expressions taken into consideration, i.e., those which relate to basic level animal cognitive models generally confirms the assumption of special cultural significance of such models, due to their superiority in numbers over non-basic categories, but in at least two cases their dominance is not unquestionable. The basic terms have been identified with regard to the criteria specified by Berlin and Kay (in Lakoff 1987: 25) for basic colour nomenclature, indicating that such words should be morphologically simple, broadly applicable as well as common or generally known, and also acquired early by children. Such terms evoke basic cognitive animal categories, which are characterized by internal 
similarity, that is, they are associated with a specific general, overall shape (gestalt), typical modes of behaviour, interactions with humans, etc., as well as external dissimilarity, i.e., are easily distinguished from other animal categories. They are also, of course, prototype-centered. The results of the survey are presented and discussed below.

\section{1. "Animals"}

In the selected source, the term animals applies, in accordance with its popular usage, only to mammals, especially the familiar, commonly known ones. Figure 1 illustrates the occurrences of terms referring to different category levels in the surveyed sample of expressions.

Superordinate term occurrences (10)

Subordinate term occurrences (17)

Basic term occurrences (188)

$\begin{array}{lllllllllll}0 & 20 & 40 & 60 & 80 & 100 & 120 & 140 & 160 & 180 & 200\end{array}$

Figure 1

Animal (mammal) terms in the surveyed sample of idiomatic expressions (215 in general)

As could be expected, the largest number of expressions involve references to common domestic animals - the dog (43), the horse (28), the cat (25), and the pig (12). It is these most common animal categories that are addressed also at subordinate levels: out of 43 references to the dog, 36 are realized by the basic word dog, 4 by the subordinate terms puppy, hound and poodle. The basic term cat is used 23 times and terms subordinate to it are used twice (kitten and pussy). A few idioms (4) contain the subcategory terms calf and lamb, while the clearly distinguished subcategory of pigs is that of hogs. The reference to subcategories is motivated by the need to highlight 
a property that is not prominent in the model represented by a more general term. Thus, from among the numerous dog breeds, it is poodles who are stereotypically the most likely to perform tricks on command (perhaps due to their popularity with circus dog trainers, which, in turn, is caused by the breed's exceptional docility), and this property is exploited in the expression to be nobody's poodle. The ability to run very fast on a hunt is typically associated with hounds rather than with all dogs, hence the subcategory is mentioned in to run with the hare and hunt with the hounds, hare and hounds (game). The subcategory terms like puppy, kitten, calf, lamb are used when such properties as plumpness, inexperience, weakness, and helplessness need to be highlighted. A subcategory of pigs, i.e., hogs (castrated, fattened males) is mentioned so as to highlight the property of immoderation and/or bulkiness, as in: a road-hog, to hog (a conversation, food, attention), to go the whole hog.

In a significant number of cases the conception evoked by a superordinate term related to the fauna, such as animal; creature; beast involves a characteristic that, although very general, is sufficient as a source notion in terms of which a specific target domain can be portrayed. Thus, the conception represented by animal, which involves the lower-order characteristics "untamed", "controlled by instincts" seems to be the basis of such idioms as behave like (worse than) an animal, political animal, animal spirits, animal passions. The relevant domain in the representation of creature is "being alive" (highlighted by creature comforts), while beast apparently activates the notion of "being inferior, non-human". It is this notion that seems to be highlighted by the expressions: the nature of the beast, the beast of burden.

\section{Rich animal ICMs - the example of the dog}

The ICMs of domestic animals are especially abundant in lower-order conceptions, so that specific aspects of those concep- 
tions, rather than whole mental images can be used as source domains in metaphorical mappings on which the meaning of idioms is based. The WHOLE FOR PART type of metonymy is involved here. For example, the stereotypical characteristic of the inferior status of dogs is exploited in expressions like every dog has his day, any stick will serve to beat a dog with, give a dog a bad name and hang him, dog's life, not to have a dog's chance, to be in the dog-house, dog-tired, die like a dog, go to the dogs. Another characteristic - that of dogs' tendency to fight for their place in a pack is highlighted by top dog; dogfight, dog doesn't eat dog, while their various typical activities are referred to in a dog in the manger, dog's dinner, sick as a dog, let sleeping dogs lie, don't keep a dog and bark yourself, his bark is worse than his bite, and you can't teach an old dog new tricks.

\section{2. "Birds"}

The study of bird terms in the selected sample, whose results are presented in Figure 2, does not directly contradict the assumption of the special cultural significance of basic-level categories, but provides evidence for the relevance of more specific, subordinate categories, at least as regards the avian part of the animal kingdom.

Subordinate term occurrences (76)

Basic term occurrences (17)

$\begin{array}{lllllllll}0 & 10 & 20 & 30 & 40 & 50 & 60 & 70 & 80\end{array}$

Figure 2

Bird terms in the surveyed sample of idiomatic expressions (93 in general) 
In Rosch's pioneering research into human cognition (cf. Lakoff 1987), the category marked by the term bird was chosen as one of the first objects of experiments which resulted in developing the notion of a category prototype. This fact indicates that the category marked by that term was instinctively assumed to represent a cognitive basic-level, despite the fact that in the biological classification, the category of birds is identified as an entire class rather than a genus, the latter category being two steps below the former, while in between there are the levels of order and family. In the biological scientific taxonomy, the class category corresponding to Birds (Aves) is that of Mammals (Mammalia), which by no means can be considered a basic-level class category. It is understandable that the category BIRDS represents a basic level in human cognition because, unlike its taxonomic counterpart MAMMALS, it is identifiable as a mental gestalt associated with a certain overall shape, as well as with a sufficient number of relevant outstanding properties. Nevertheless, as a study of idiomatic expressions involving bird terms indicates, the more specific categories, e.g., LARK, CUCKOO, DOVE, PEACOCK, PARROT, and especially those closest to human experience - CHICKEN, COCK, DUCK, GOOSE, are referred to much more frequently as source domains in metaphoric mappings than the basic one (BIRD). The simple reason is that when it comes to highlighting certain human properties, such as pugnaciousness, timidity, miserableness or vulnerability, they are more likely to be found in stereotypically detail-laden ICMs of popular bird genera and species. The class term bird, which evokes a more general and sketchy model is of less use in such cases.

\section{3. "Fish"}

As the evidence of idiomatic expressions indicates, in the case of aquatic organisms, the folk basic level of categorization is not as specific as that of genus. As in the case of birds, the class term fish evokes a cognitive model sufficiently equipped 
with relevant properties which can support a fair number of metaphoric mappings. As is usual, more specific generic terms, labelling cognitively subordinate categories are used in idiomatic expressions when a characteristic relevant in a given situation is not prominent in the stereotype of the more general category FISH, for example slipperiness in as slippery as an eel, being a popular canned food in packed like sardines, greed, and fierceness in to be a shark. Consequently, as Figure 3 illustrates, the more specific ICMs are evoked in idiomatic expressions almost as frequently as the more general folk basic one. Therefore, in the case of birds and fish the basic level ICM is rather scanty, which indicates that in human cognition these categories of animals are approached with less scrutiny than mammals.

Subordinate term occurrences (10)

Basic term occurrences (13)

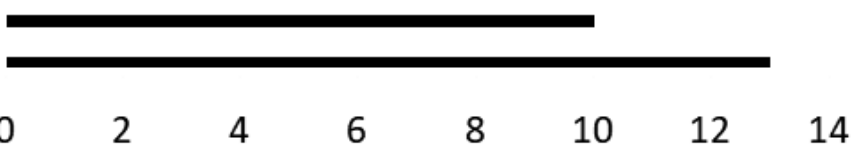

Figure 3

Fish terms in the surveyed sample of idiomatic expressions

(23 in general)

\section{4. "Insects"}

In the considered sample of idiomatic expressions, the number of occurrences of superordinate folk terms for small, creepycrawly creatures, i.e., worm, bug, which cover insects but also spiders and small mollusks, such as limpets or leeches, is almost equal to the number of occurrences of generic terms $(f l y$, bee, wasp, flea) referring to the cognitive basic level categories in this section of the animal world. Terms for subordinate insect categories are used just twice - drone, nit - to highlight relevant properties, those of the monotonousness of emitted 
sound and unpleasantness combined with small size, respectively.

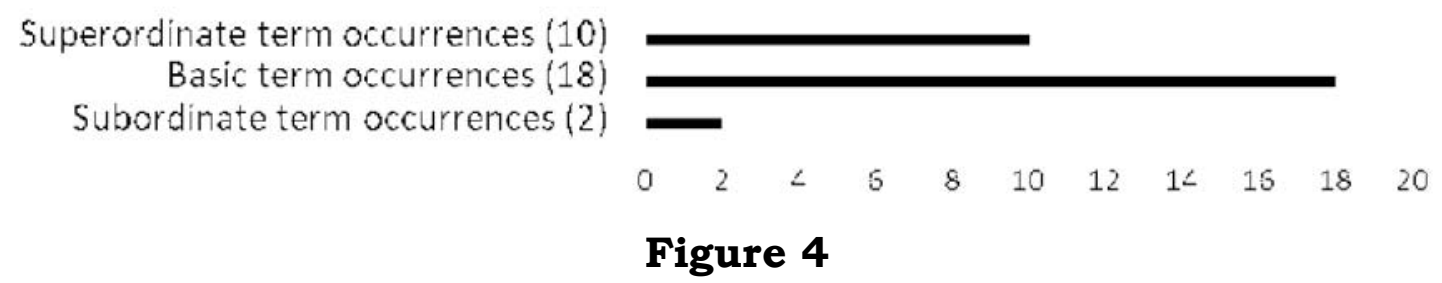

Insect terms in the surveyed sample of idiomatic expressions

(30 in general)

\section{Conclusions}

The claim that basic-level categories (in the selected example of animals) named by basic language terms have greater cultural significance is confirmed by the study of the use of terms referring to them in fixed, highly conventionalized idiomatic expressions whose meaning is typically metaphorical in nature. However, the claim that the folk generic level coincides with the scientific generic level, as suggested by the outcome of the research into the Tzeltal plant classification, reported in Lakoff (1987), as well as in Ungerer and Schmid (1996), is slightly far-fetched.

Nevertheless, the study of the selected sample of linguistic material indicates that, as regards the English fauna terminology, basic language terms show that basic-level cognitive categories are established exclusively from the practical human perspective. They function at the folk-generic level which does not need to coincide with the scientific generic level at all, as could be assumed. In fact it is scientists who "borrow" common folk terms constituting basic terms in a language and apply them to categories which they evaluate as basic or generic, taking into account criteria which are not always relevant or even discernible in casual cognition. 


\section{References}

Gulland, Daphne M., David Hinds-Howell (1986). The Penguin Dictionary of English Idioms. Harmondsworth, Middlesex: Penguin Books.

Lakoff, G. (1982). Categories and Cognitive Models. Linguistic Department and Cognitive Science Program, University of California at Berkeley.

Lakoff, George (1987). Women, Fire and Dangerous Things. Chicago: Chicago University Press.

Searle, John R. (1977). "A classification of illocutionary acts". In: A. Rogers, B. Wall, J. P. Murphy (eds.). Proceedings of the Texas Conference on Performatives, Presuppositions and Implicatures. Arlington, Va.: Center for Applied Linguistics, 27-46.

Taylor, John R. (2002). Cognitive Grammar. Oxford: Oxford University Press.

Turner, Mark, Giles Fauconnier (1995). "Conceptual integration and formal expression". Metaphor \& Symbolic Activity 10/3: 183-204. Also available at <https://www.researchgate.net/publication/22 8300228_Conceptual_Integration_and_Formal_Expression>.

Ungerer, Friedrich, Hans-Jörg Schmid (1996). An Introduction to Cognitive Linguistics. London - New York: Longman.

Webster's New World Dictionary of the American Language (1979). Cleveland, Ohio: William Collins Publishers, Inc.

Olga Sokołowska

ORCID iD: 0000-0002-4722-113X

Instytut Anglistyki i Amerykanistyki

Uniwersytet Gdański

ul. Wita Stwosza 51

80-308 Gdańsk

Poland

angos@ug.edu.pl 